\title{
Reconstructing the Distorted Image of Women as Reproductive Labour on the Copperbelt Mines in Zambia (1920-1954)
}

\section{Lilian Cheelo Siwila}

\section{Abstract}

The article addresses the conceptualising of the presence of women in the Copperbelt mine compound in Zambia during the period 1920 -1954. Like many other mining companies across Southern Africa, The British South African Company which owned the mining rights on the Copperbelt imposed certain restrictions on women who came to the Copperbelt province. Initially mine owners did not favour the idea of allowing women to live in the mine compound for the fact that women were seen as a distraction to production in the mines. The outcome of this decision was that as time went by, most of the men left their jobs to return to the villages to be with their spouses. Those who were single took advantage of the neighbouring villages during weekends and stayed on with their girlfriends and sometimes only returned back for work later in the week. This affected production in the mines and made the mine bosses to propose rules on how to incorporate women in the mine compounds. The aim of this study is to demonstrate how patriarchy played an important role in excluding women from participating in the economic development that took place on the Copperbelt during that period. The article further highlights ways in which the colonial government displayed some ambiguities in the exclusion and inclusion of women in the economic development of the Copperbelt mines. It will also show how labour markets exploited women's rights to participate in the economic development in the Copperbelt and how, when access was granted, women's productive and reproductive labour was used as part of an economic drive strategy. It also further argues that when it comes to women's bodies, throughout history, religion has played an important role in defiling women's bodies. It is this negative perception that was also perceived in the mining company in the Copperbelt during the period under study. While women were seen as a threat to economic development, their presence in the Copperbelt also played a significant role in the economic 


\section{Lilian Cheelo Siwila}

development of the Copperbelt mining companies. Therefore, women's contribution during the foundation of modern African life in Zambia needs to be acknowledged in our intellectualising of the development of the Copperbelt mines.

Keywords: British South African Company, Copperbelt mines, women. Women's bodies, production and reproduction, Religion, labour market.

\section{Introduction}

A historical study of gender during the colonial era will show that although colonial masters and missionaries may not have used the concept of gender in their debates on women, gender differences still played a significant role in the way in which these colonial masters and missionaries perceived the position of women in society. A critical analysis of the history of colonialism in Africa reveals that African women suffered a double oppression during this period. Firstly, women suffered the patriarchal oppression derived from their African cultures; second, the western patriarchal colonial system oppressed them further. The oppression faced by African women during this era has contributed to how women who leave their homesteads in the rural areas to go to the city to seek economic stability are viewed by society, even today.

In the Zambian context, the history of industrial development that took place in the Copperbelt province in the 1900s presents an ambiguous position in the way in which women were perceived by both colonial masters and the missionaries. Most of the literature presents a negative perception of women in the urban city during this period. What normally comes to the fore, is what Hodgson and McCurdy (2001) call 'the wicked woman' phenomenon. One who is a 'vagabond', 'a prostitute', 'wayward', 'unruly', 'indecent', and 'immoral' (Hodgson \& Mc Curdy 2001:1). Interestingly the wicked woman phenomenon that was so pronounced during this era continue to be used in the representation of women, even in the present context. In most of the Zambian villages, the dominant discourse for unskilled women who leave the village to go to the city to look for employment, especially without the accompaniment of a husband, remain negative. These women are defined as wicked with a mind-set that says that the only work they would be able to perform in the city, was that of prostitution. Hence they are viewed as irresponsible citizens. 


\section{The British South Africa Company and the Migration of Women into the Copperbelt Province}

A brief background of the colonial era in Zambia shows that since the advent of colonialism, Zambia has undergone a complex social, economic, political and religious transition. The country moved from a traditional self-sustaining agricultural economy, to a strong capitalist economy that mainly depended on copper. Zambian communities progressed from a tribal and clan-based oriented type of leadership to the amalgamation of different ethnic groups under the umbrella of one system of colonial control. The merger of ethnic groups came about as a result of movements from the rural areas into the urban cities where people from different ethnic groups came together and engaged in paid labour. Although European contact with what is now called Zambia date from as early as $15^{\text {th }}$ century with the coming of the Portuguese traders, colonial rule had its impact and effect on the country from around the $19^{\text {th }}$ century when European explorers, missionaries, visionaries and those on adventure came to the country, now called Zambia (Ndulo \& Kent 1996:257). From a Christian perspective, David Livingstone stands out as a first prominent figure that visited the country during the $19^{\text {th }}$ century in an attempt to open up a way for the acceptance of Christianity in central Africa. And from an economic perspective, the Charter that incorporated Zambia into the British South African company, and also gave Zambia access to its broad monetary and administrative systems, opened doors for economic development in the country ${ }^{1}$. This move was also influenced by figures such as John Cecil Rhodes who was one of the main founders and shareholders in the then developing empire of gold and diamonds in South Africa (Ndulo \& Kent 1996:58)2 ${ }^{2}$ The British South African Company became the first mining company to invest on the Copperbelt province of Zambia. During this period, the Copperbelt province became the hub for economic development and attracted many men who migrated from rural areas to go and work in the mines. At first the mobility attracted only men but as time went by, women too, began to leave the villages heading to the Copperbelt region in search of employment.

\footnotetext{
${ }^{1}$ That said, though, Zambia remained a colonised country, and subjected to a colonising economy.

${ }^{2}$ For a more detailed account on the history of the role of British South African Company in Zambia see Slinn (1971).
} 


\section{Factors that Led to the Migration of Women to the Copperbelt} As at the beginning of the Great Depression (29 October 1929), it was difficult to find any group of people in Zambia who were not enormously dependent on the market economy. Prior to the Great Depression, most of the Zambians have become part of the money economy, and started to earn cash income. This also meant the migration of long distances from home, to look for work as wage labourers in industries such as the mines in the Copperbelt, and in South Africa. Within this economic awakening, scholars have argued that towards 1939 at the end of the Great Depression and the beginning of World War II, there was also a growing desire among native women to seek status by finding wage work, and so, become more independent. This also led to the migration of women into the cities, especially in the Copperbelt province. Due to this historical process, we cannot understand the current Zambian society in relation to women migrating into the cities, unless we closely look at the history of the foundation of modern life in the country. This is so, because it was during this time that the market economy began to control the lives of both men and women. This is also the period that marked women's desire for income generation and modern living. Parpart (1994) argues that an important phenomenon that accompanied this event of men and women going off to look for work in the Copperbelt, was the newly found independence and selfassertiveness of the young women. Without going so far as to call it a definite movement, because it was not officially organised or institutionalised, Parpart notes that it just developed as part of this very significant event in the history of Zambia. Women started to assert themselves, and society at large started to recognise women's rights.

Despite this growing interest among women to leave their homesteads and migrate to the cities, we see much resistance to this movement of women to the cities, from not only the colonial government, but also missionaries and traditional leaders, especially through the indirect rule system then in place. The refusal of women to migrate into the Copperbelt was associated with a number of reasons, ranging from gender, and cultural factors, to economic factors. There were also ambiguities associated with the decisions made by both missionaries and colonisers in response to the issue of women migrating to the Copperbelt. For instance, at one point women's presence was acknowledged by the mine authorities as an incentive for male mine workers who had to rely on women's domestic and sexual services. According to mine 
authorities, this helped to boost production as it prevented men from going back to the villages more often. Chauncey Jr. (1981) observes that the decision to allow the women into the mine compounds also came as a result of competition for mass production within the mining sector. Chauncey (1981) further states that by the 1920s copper mining companies in Northern Rhodesia were faced with a challenge of labour migration in the neighbouring countries where conditions were better than those of their homeland. This challenge forced the mining company to look for incentives that would attract the mineworkers, and one suggestion was to allow women to come and live in the mine compounds. On the other hand, even when these migrating women were allowed to stay in the mine compounds, they still had to adhere to strict rules.

The permission for women to stay in the mine compounds came with conditions. One of which was that all women residing in the mine compounds were to be under the control of a male. Practically, this means women needed to be married to a miner in order to qualify to live in the mine compounds, while single women were to register their presence with the mine authority. The aim was to help control their movements to the mine compound. Single women who wished to stay in the mine compounds could also take on temporary marriages as encouraged by the mine authority. How long these temporary marriage arrangements lasted was not an issue as long as all women were under the control of a man. Parpart states that those women who wished to register their marriage were given a copper bracelet called (chingolongolo) to wear as a sign that they are married to mine workers (1994:257). From this fact, Chauncey made the deduction that the decision to permit women in the mine compounds was made explicitly for the sexual, domestic and other services women provided, as non-monetary inducements for men to work in the Copperbelt, and despite the low wages they earned (1981:137).

On the other hand, the colonial government, traditional leaders and missionaries were against the influx of women into the Copperbelt, especially single women, as these were seen as a threat to what was termed as the 'traditional moral code' of society due to the fact that they were not under male control. As the influx of women coming to the Copperbelt from the rural areas increased, the mine authority became more and more threatened by the presence of women, especially single women, in the compounds. This led to the introduction of stricter rules for women entering the Copperbelt province. In the rural areas, the chiefs introduced a penal code through the indirect rule system, that saw the arrest of any woman who attempted to enter the mining 


\section{Lilian Cheelo Siwila}

towns without a warrant/ permission. Chiefs worked with the colonial government to also arrest any driver of a car or truck, found carrying women into the Copperbelt. Roadblocks were introduced in the key entry points into the city. This kind of domestication of women by the colonial government simply reinforced the African cultural oppression of women, that was already dominant in most African societies. It further entrenched the idea of men relying on and using women's domestic labour, as it institutionalised and policed the restrictions put upon women's mobility.

\section{Women as Reproductive Labour as a Tool for Economic Productivity}

Scholars such as Chauncey (1981), Hansen (1984), and Parpart (1994), are among the few who have produced extensive literature on the experiences of women in the Copperbelt mining towns, as they had to function as part of reproductive labour. When the decision to allow women to move from rural areas to the urban city was enacted, the women were already seen as coming to provide services to male mineworkers, other than coming as workers who will contribute to the industrial labour market themselves. This is because mine work was seen as a man's job. This meant that women's labour, be it productive or reproductive, was placed under the company's supervision as part of an unpaid labour force. They would only function as an indirect supporting labour force that would be necessary for the increase of productivity output on the mines. Chauncey states that the idea of relocating women's reproductive labour from the rural to urban areas under the influence of mining companies as controlled unpaid labour (own words) was a great benefit to the company. He further comments that:

From the perspective of capital, women's labour was reproductive, that is, it provided for maintenance of mine employees. But from the perspective of women, such gender-specific labour tasks such as the provision of domestic and sexual services and the production and exchange of commodities such as beer and vegetables represented productive labour (1981:136).

Although Chauncey seems to view this kind of service positively, writing from a feminist standpoint, my view is that the mine employers also exploited 
women's labour. At a time of the Great Depression and economic migration, when everyone was trekking to the city for economic benefit, women were still perceived as domestic labour providers who either needed to remain in the confines of the home in the village or be used as domestic labour in the city, and on the mines. The concept of viewing women as reproductive labour meant the commodification of women's labour, both concerning their abilities and their bodies. The kind of approach adopted by the mine bosses was also culturally influenced by the Victorian model of the obedient, non-working housewife, who was also very common in their own context during that period. Both Semitic religions and the modern developing world economy, have in many ways been found guilty of the upholding and the cultural implementation of the Victorian model of the perception of women. At the same time the model also found a home in the African cultural context, which also saw women as home makers and 'service providers for the male'.

Besides viewing women as objects for economic productivity mine bosses also reinforced mechanisms that controlled women through social surveillance. This was done through controlling their migration into the city and controlling their movements while they were in the city. Women's surveillance was a combined effort between the colonial government and the missionaries who also used their own biblical ideology of a woman's position in society in their judgements and proclamations. According to Parpart (1994), missionaries saw single women as sinners who indulged in adultery. To them, 'the evils of town life' was a danger to women's lives. Therefore, women were better off remaining in the villages where they would not be influenced by city life. What is interesting with such kind of approach is that western women were already in the city and little was said about their presence or being influenced by the dangers of city life. A feminist reading of these kinds of perceptions and practices, reveal them to be not only Victorian, but also patriarchal, and oppressive of women, stifling their quest fro self-development and selfadvancement, especially African women.

Besides the missionaries and mine employers, traditional leaders controlled women's movement into the city, by working with the colonial authorities through the indirect rule system. They prevented women from leaving the rural areas, by their policing of the border posts that were created between the rural and urban areas. Women who were coming to the city needed to get permission from their traditional leaders and those who were caught travelling without boarding passes obtained from the traditional leaders were repatriated 


\section{Lilian Cheelo Siwila}

back to the village (1994:271). This means that the border controls that were set up by the colonial government also became empirical points of gender discrimination and the systemic oppression of women. In this, the colonial government and the traditional authorities found common cause. Any overstepping of these rules was seen as threatening to the moral order of society and the offender was fined to the point of imprisonment ${ }^{3}$. Jane Parpart describes how,
$\ldots$ in the late 1930s and early 1940s these courts encouraged the mine police to search the compounds for single women who had come to town without permission from their chiefs. They had to pay 10 pounds fines and were repatriated. If a woman admitted having committed adultery, she was fined 5 pounds and declared immoral. She could not claim damages from the man. A woman who had married three different men was viewed as a prostitute and banned from the Copperbelt (1994:5).

Despite these restrictions, what is interesting, is that at one point these mine authorities ignored the call to stop these single women from coming into the cities from the villages. This was breaking the triangular colonial-missionarytraditional authority agreement on the moral and penal code that was to be followed with regard to women. As far as the mining authorities were concerned though, they have changed their views on the usefulness of women on the mines, and that this was more important than continuing subscribing to the moral order agreement. On the one hand, capital accumulation, and the unrestricted exploitation of the reproductive labour became the order of the day. On the other hand, this practice was embedded in the age-old exploitation of women's bodies, embedded in the negative perception of their bodies. This is most crucially revealed in feminist discourses on the 'male gaze'. The male gaze, has, for centuries, dominated women's bodies, with no counter response from women themselves. Women have been and still are to a large extent, the objects of men's voyeurism and desire, which simultaneously degrade their bodies to the status of an object (2000:53).

When discussing issues relating to women's bodies we should always remind ourselves that both religion and theology are not innocent of the negative perception of women and their bodies. The Church Fathers used their

${ }^{3}$ See Parpart, 'Where is Your Mother?' (1994). 
patriarchal powers to refrain women from allowing women full participation in the activities of the church, mainly because of what they are, and not who they are (Watson 2001). Their femaleness was viewed negatively, as something to be used and exploited - their bodies and sexuality - while their abilities and competencies were not recognised nor appreciated. Isherwood shows that the early fathers tried to describe ways in which women should behave, as a way of controlling and governing them. They made it a point that a woman's world was very confined and many women were advised to remain indoors. Male patriarchs prescribed how they ate, slept, bathed, and spoke (2000:27). Similarly, it is evident that the prohibition of women's free movements to the Copperbelt and the measures that aimed at preventing them from full participation in the economic and cultural development of the province, had more to do with women's bodies that were under surveillance by the male powers, and it used them for male satisfaction and the money economy, than with the so-called moral order itself.

The other point that this study addresses with regard to the negative perception of women during this period was on the term used to describe women. One of the gender constructs that was commonly used to oppress single women who left their homesteads to go to the Copperbelt mine towns to seek for economic security was prostitute. The reason for being called prostitutes was mainly because these women were associated with the selling of their sex for money. Hodgson and McCurdy talking about the colonial perception of prostitution state that for the colonial government prostitution was a serious term that was dehumanising to women. It also created complicated alliances and antagonisms between husbands, fathers, lovers and the state officials who were concerned about controlling women's sexuality (2001:10). Mutesi (1976) argues that the single women who came to the Copperbelt were not the 'good' wives, as they were supposed to be. The notion of the 'good' wife was traditionally contrasted with the prostitute. Polinsk, for instance states that:

... the socially accepted image of a 'good' woman in the Middle Ages was an image of a fully clothed woman. A fifteenth-century depiction of a virtuous woman contrasts her with a prostitute. The prostitute is partially unclothed, her breasts visible and her body flaming with lustful desire; the good woman is a bloodless creature, "pure and chaste and never disturbed by the unruly prompting of sexual desire. 


\section{Lilian Cheelo Siwila}

The good woman was therefore a safe woman whose sexual body was carefully hidden and who subdued her sexual needs (2000:52).

This kind of conceptualisation of women stated by Polinska suits the reflection given by the moral order - that the mine bosses, missionaries and traditional authorities projected on African woman who left the rural areas for the city, or to come to the Copperbelt. For them, prostitutes were perceived through physical appearance, yes. But, at the same time, the mere leaving of the village to go and work in the city, was also viewed as a woman aspiring to be a prostitute. A gender analysis of this kind of perception would raise questions on issues around work. To say that women came to the city to be prostitutes without considering other kinds of work that they could be involved in, creates a negative perception of women as people who were simply focused on selling their bodies. Hodgson and McCurdy contend that 'wickedness' can also be described as a discourse of primary masculine power that seeks to control or oppress women by stigmatizing certain actions whether normative or unconventional (2001:10). The naming of women as 'prostitutes' or being 'wicked' while using their reproductive labour as social reproduction and the money economy, as was the case on the Copperbelt during the colonial era, continues to be reflected in the current market system. Companies, worldwide, have used women's bodies through media, to advertise and promote their products. The use of the female body in today's market economy, then, is similar to its use by the colonial mining companies - as a supporting cast for (colonial) market capital production and accumulation.

So, the way in which female domestic labour was viewed in the modernising labour economy in Zambia, did not recognise and honour women as part of the developing industrial production complex on the Copperbelt. This resonates with Luxton's view that discourses on women's reproductive and domestic labour has been and continues to be one of the central labour processes of industrialism. This particular and indispensable labour converts the wages of the paid workers into the means of subsistence for the entire household and replenishes the labour power of household members so that it can be resold (1980:14). In this process, the role of women, even as they were not recognised as equal in the developing economy, is still repressed. In the Copperbelt mining company the presence of domestic labour provided by women helped to boost production in the mines. In this historical context, a gender perspective on domestic labour reveals that labour markets need to be 
made aware of the fact that social reproduction forms the backbone of economic production; therefore, the two cannot be separated. In this sense, social reproduction can be associated with activities, attitudes, responsibilities and relationships directly related with the maintenance of life on a daily basis ${ }^{4}$. Therefore, what most African women provided in the developing colonial economy, that needs to be appreciated, is their social reproductive labour. Even though this has to be acknowledge, it also remains problematic, as stated. Hence, Ferguson (2008) raises the question as to what it is that makes women's labouring bodies that opens up the possibility for the inevitable exploitation by capitalism. The controlling and domestication of women's bodies by the capital system and patriarchy also exert forms of power, control, and surveillance on the competitive market economy.

With regard to power, Poling argues that social power inequalities become occasions for the abuse of power. Those who are powerful can organise societies in such a way that those who are vulnerable are denied the full resources that life has to offer (1991:29). This was clearly the case with women on the Copperbelt who found themselves on the side of the powerless. Hence, they were denied the right to and opportunities to access resources in the city. In religious context, especially in Christian history, such power has been exerted over female bodies, in the name of divine truth (Isherwood \& Stuart 1998:11). Moreover, throughout religious history, debates over the female body continued to be deliberated by patriarchal protagonists and patriarchal systems that, in principle viewed women as of a lesser human dignity than men, if not as wicked and evil, or as dangerous or a source of pollution. The power to control female labour was one of the deadly patriarchal weapons that was used against the dignity of women, by the mine bosses, the traditional leaders and missionaries of this era. According to Lisa Isherwood (1998:27), this was all embedded in the symbolic power emanating from the British laws of the time. This echoed the British laws that also controlled the Zambian government during this period. According to these laws, men had to marry women, to make them legitimately reside in the compounds. According to the 'moral code', adultery and also rape, were prohibited. Yet, we can argue,

4 For more information on feminism and social reproduction see. Kate Bezanson and Meg Luxton (eds.) Social Reproduction: Feminist Political Economy Challenges Neo-Liberalism, Quebec: Mc Gill- Queen's University 2006. 


\section{Lilian Cheelo Siwila}

that even if women themselves did not get raped, the system raped them. Women were being raped by the system that saw their bodies as a space for economic production, and reproduction. Patriarchy, when it presents itself on the global market, then also carries along with itself, women's bodies, as spaces for socio-economic, cultural and religious production. Conversely, injustices that do not value the dignity of women, emanating from gender inequalities, are rooted in patriarchy and sexism.

Lastly the effects of globalisation to women's social reproduction and how the woman's body continues to be used as a sight for productivity in capitalist economies continue to be reflected in International organisations such as the World Bank, the International Monetary Fund and the World Trade Organisation who have in some ways benefited from this trend. For example, the feminisation of poverty and HIV and AIDS carry along some aspects of feminine vulnerability. Women are seen as the most affected with poverty yet they are also in the forefront to eradicate poverty in their households through economic care and social production. Just as in the copper mining industry of Zambia during colonial times, where women, despite being the key figures that formed the base for production, were marginalised, globalisation continue to increase the peripherization of women in the global market economy.

\section{Religion and Women's Liberation}

Religion on its own has been very slow to address many of the issues around women's productive and reproductive labour. The question then is whether religion is capable of lifting the negative injunctions against the female body as was reflected in the Copperbelt during the colonial era (see Althaus-Reid \& Isherwood 2008). Among the many different kinds of 'theology', it is especially liberation theology that has been able to challenge the church to respond positively to issues of oppression, by siding with the oppressed, and marginalised. This however is not always the case especially on issues relating to women. Often, we see religion taking the position of the oppressor especially on matters relating to women's sexuality. For example during the period under study, missionaries on the Copperbelt province took a very negative position on single women. They were in the forefront to condemn single women who entered the Copperbelt in search for economic development and advocated for the repatriation of any woman who tried to enter the Copperbelt to seek for 
self-empowerment. In this regard, I propose that a feminist liberation theology that take into account women's liberation from all forms of oppression, must be encouraged, especially when seeking the liberation of women from economic oppression. Hence, there is a need for African women religionists and theologians to begin engaging in a dialogue on African feminist liberation theology, as an appropriate theory to address the plight of women in the economic arenas of our developmental economies. These are in effect saturated with male figures.

On the other hand we also see the ambivalence in the way in which the female body was constructed by the colonial government, both as a site of economic productivity, but also as a site of struggle. It was controlled by patriarchal structures that have objectified women and denigrated their bodies (Polinska). In this regard, Mary Douglas's (2000) view rings true, namely that the body often becomes the symbol of the social and religious structures to which it belongs and anxieties of society are played out on the human body.

\section{Conclusion}

The history of women in the Copperbelt mine towns has attracted a number of research papers. Most of this research, focus on how women lived out their lives as reproductive labour, and on the role that colonial government, in collaboration with traditional authorities and missionary establishments, played in controlling and regularising African marriage relationships. In this article 1 have tried to push the agenda further by focusing on the fact that these women in actual fact were forced into domestic labour relationships as part of social economic reproduction for the benefit of the British South African Mining Company. The article has shown how women's presence in the Copperbelt, although seen as an incentive for women by other scholars, was also accompanied by a kind of sexual abuse. This is seen from the way in which mine and traditional authorities controlled women's bodies. From a religious perspective, 1 conclude this article, proposing for a need to address issues affecting women, using African feminist liberation theory. Apart from contextual needs, this is also needed, so as to deconstruct and transform, the ways in which especially religious history has viewed women's bodies. We need to move beyond ambivalent perceptions of women's bodies and their productive and reproductive labour, to an equal and just recognition of the hopes and aspirations of women with regard to the improvement of their own 


\section{Lilian Cheelo Siwila}

lives, as well as that of their families. These hopes and aspirations have always been there, and should be recognised. Women have sought the improvement of their lives, and aspired to be part of the developing African economies. So, at the same time that we recognise women's historical contributions to our continent's economies - despite numerous obstacles and repressions - by developing a more focused women's liberation theory and theology, we need to create more space for them to realise their own hopes and dreams today. This needs a greater women's liberation sensitive lens for research, as well as a gender sensitive lens, more broadly speaking.

\section{References}

Althaus-Reid, M. \& L. Isherwood 2007. Slicing Women's Bodies: Christianity and the Cut. Mutilated and Cosmetically Altered Believers. In AlthausReid, M. \& L. Isherwood (eds.): Controversies in Body Theology. London: SCM Press.

Bezanson, K. \& M. Luxton (eds.) 2006. Social Reproduction: Feminist Political Economy Challenges Neo-Liberalism. Quebec: McGill- Queen's University.

Bula, O. 2014. Threats to Women's Rights and Dignity: Tourism and Gender in Africa. In Caesar, D., L. Wati \& M. Phillip (eds.): Deconstructing Tourism: Who Benefits? A Theological Reading from the Global South. Kway Jen: Programme for Theology and Cultures in Asia.

Chauncey, G. Jr. 1981. The Locus of Reproduction: Women's Labour in the Zambian Copperbelt, 1927-1953. Journal of Southern African Studies 7, 2:135-164.

Douglas, M. [1966] 2000. Purity and Danger: An Analysis of Pollution and Taboo. New York: Routledge and Kegan Paul Ltd.

Ferguson, S. 2008. Canadian Contributions to Social Reproduction Feminism:

Race and Embodiment Labour. Journal of Race, Gender and Class 15,1/2: 42-57.

Hansen, K.T. 1984. Negotiating Sex and Gender in Urban Zambia. Journal of Southern African Studies 10,2: 219-238.

Hodgson, D.L. \& S. McCurdy 2001. Introduction: 'Wicked' Women and the Reconfiguration of Gender in Africa. In Hodgson, D.L. \& S. McCurdy (eds.): 'Wicked' Women and the Reconfiguration of Gender in Africa. Cape Town: David Philip Publishers. 
Isherwood, L. 2000. Sex and Body Politics: Issues for Feminist Theologies. In Isherwood, L. (ed): The Good News of the Body: Sexual Theology and Feminism. Sheffield: Sheffield Academic Press.

Isherwood, L. \& E. Stuart 1998. Introducing Body Theology. Sheffield: Sheffield Academic Press.

Luxton, M. 1980. More than a Labour of Love: Three Generations of Women's

Work in the Home. Toronto: Women's Educational Press.

Mc Fague, S. 1993. The Body of God. Minneapolis: Fortress.

Miles, M.1991. Carnal Knowing. New York: Vintage.

Mutesi, A. 1976. 'Prostitution on the Copperbelt'. In Robbins, K. \& K. Rennie (eds.): Social Problems in Zambia: Studies in Zambian Society. Lusaka.

Ndulo, M. \& R.B. Kent 1996. Constitutionalism in Zambia: Past, Present and Future. Journal of African Law 40,2: 256-278.

O'Connor, J. 1995. The Epistemological Significance of Feminist Research in Religion. In King, U. (ed.): Religion and Gender. Oxford: Basil Blackwell. Parpart, J. 1983. Class and Gender on the Copperbelt: Women in the Northern Rhodesian Copper Mines 1926-1964. In Robinson, C. \& I. Berger, (eds.): Working Papers. Available at: http://afsaap.org.au/assets/1984_ParpartJane-L.pdf.

Parpart. J. 1994. 'Where is Your Mother?': Gender, Urban Marriage and Colonial Discourses on the Zambian Copperbelt, 1924-1945. International Journal of Historical Studies 27,2: 241-271.

Poling, J.N. 1991. The Abuse of Power: A Theological Problem. Nashville: Abingdon Press.

Polinska, W. 2000. Dangerous Bodies: Women's Nakedness and Theology. Journal of Feminist Studies in Religion 16,1,Spring: 45-62.

Ruether, R.R. 1983. Sexism and God-Talk. London: SCM Press.

Slinn, P. 1971. Commercial Concessions and Politics during the Colonial Period: The Role of the British South Africa Company in Northern Rhodesia 1890-1964. African Affairs 70,28: 365-384.

Watson, N.K. 1996. Introducing Feminist Ecclesiology. Sheffield: Sheffield Academic Press.

Lilian Cheelo Siwila School of Religion, Philosophy and Classics University of KwaZulu-Natal Pietermaritzburg Siwila@ukzn.ac.za 